\title{
In the Covid-19 pandemic, Brazil sees the SUS
}

Ana Maria Costa1,2, Maria Lucia Frizon Rizzotto1,3, Lenaura de Vasconcelos Costa Lobato1,4

DOI: 10.1590/0103-1104202012500I

AT THE TIME OF WRITING THIS EDITORIAL, 122 days have passed since the first Covid-19 case was registered in Brazil, confirmed in São Paulo, on February 25, 20201. The pandemic found the nation with a militarized, ultra-right government, bewildered and submerged in a political crisis, aggravated by a low performance of the economy with growth of the Gross Domestic Product (GDP), in 2019, of only 1.1\% and adding up to approximately 13 million unemployed citizens. This combination of factors and crises has deepened political instability and has proved to be tragic from all points of view, making the country seem like a ship with no direction, ready to sink.

Today, we have 928,985 confirmed cases of infected with Sars-CoV-2, although the estimates warn to figures at least 8 to 10 times higher due to the low testing practiced in our territory. In a pace of accelerated growth, more than 20 thousand new diagnosed cases are registered daily, regrettably accumulating 53,895 deaths, of which 1,185 in the last 24 hours $^{2}$. With these data, Brazil becomes the second country in number of deaths, surpassed, at the moment, only by the United States.

The pandemic has hit the core of society's narcissism, always fueled by satisfaction with the denial of reality. The abysmal social inequality is now wide opened as scandalously exposed as it had previously been denied. The Brazil that will emerge from this health crisis will no longer be able to hide from itself the image that revealed its millions of poor and miserable people without minimum conditions for complying with the sanitary standards recommended for the control of the pandemic: staying at home, maintaining social distance, washing hands, and eating properly. This mirror, if not broken again - and the uncomfortable image, once again forgotten -, will require radical changes in the development model and in economic policy. The transformations involve admitting that a fairer and less unequal country is only possible through the adoption of an unorthodox economic policy that institutionalizes universal social protection mechanisms, guaranteeing a basic citizenship income and promoting an effective increase in public investment to expand the labor market and absorb the Brazilians who are found completely abandoned today 3 .

The $\mathrm{R} \$ 600$ emergency aid, approved by the National Congress, instead of the $\mathrm{R} \$ 200$ proposed by the federal government, has already been requested by $43 \%$ of the Brazilian population; and of these, only $60 \%$ received at least a portion of the money ${ }^{4}$.

The result is in the 'disobedience' to health recommendations, reflected in the extremely low isolation rates found in large Brazilian cities and states which, even in a lockdown situation, are unable to reach the desirable levels of social distance. Without the support of

\footnotetext{
1 Centro Brasileiro de Estudos de Saúde (Cebes) - Rio de Janeiro (RJ), Brasil. dotorana@gmail.com

2 Escola Superior de Ciências da Saúde (ESCS)

- Brasília (DF), Brasil.

3 Universidade Estadual do Oeste do Paraná (Unioeste) - Cascavel (PR), Brasil.

4 Universidade Federal Fluminense (UFF) - Niterói (RJ), Brasil.
} 
the emergency aid or another way of guaranteeing income, precarious workers cannot stop working and use the crowded public transport that continues to circulate in large cities. It is this same population accustomed to drug traffic and militias that live with police violence, growing in times of evident installation of authoritarianism in the country 5 .

The difficulties with the payment of the aid, registered in the thousands of responses 'under analysis' of the Caixa Econômica Federal app and in the immense queues at the banks' doors, are not just management problems. If it wanted to speed up payments and identify Brazilians with an effective right to the aid, the government would have used the structure of the Unified Social Assistance System (Suas) and expanded the banking network to effectuate payment. On the contrary, the aid was centralized at the Caixa Econômica Federal and administered by the Ministry of Economy, without the participation of the Ministry of Citizenship, which has (or had) the technical and technological apparatus to deal with social programs. What was lacking was a commitment to mobilize the knowledge and the ability to deal with people's problems, since the government's economic project is based exclusively on cutting spending and privatizing.

The social anti-protection logic was even more serious in the deliberate action of dismantling the Ministry of Health, with the dismissal of technical staff and the replacement of three ministers since the beginning of the pandemic, now directed by a disciplined military man, more obedient to the government's political desires than the health needs of the population, who does not know the geography of his own country and knows nothing about health and the Unified Health System (SUS).

Another situation of enormous gravity is the lack of leadership that will lead Brazil to facing the pandemic, since the president himself chooses to generate political crises with the Powers of the Republic, in which he adopts a negationist position, minimizing the severity of the disease and the extent of the pandemic, guiding the population in the opposite direction to that indicated by science, by national and international health organizations, and by the experience accumulated by other countries. This omission of the role of leader of the Nation undoubtedly contributes to the expansion and to the aggravation of the health tragedy, whether by the ambiguity in the communication, or by the lying indication of drugs without proven efficacy. The refusal of the federal government to responsibly conduct actions to control and mitigate people's suffering during the pandemic has led governors and mayors, in line with the public interest, to take over the process, even under strong and constant attack of the president and without the national coordination of the Ministry of Health.

This profound helplessness of the Brazilian people reveals the value and importance of the SUS, which, despite its historical weaknesses, looms large in the face of the challenge and, with all sacrifice, faces the pandemic. The shortcomings and difficulties, which were already visible due to the chronic underfunding of the System, were brutally aggravated by the Spending Ceiling Amendment (EC-95), which freezes investment in social policies for 20 years. According to the National Health Council, the SUS lost, in 2019 alone, R $\$ 20$ billion with EC-95. Fighting precarious conditions to save lives, thousands of health professionals become infected and fall ill due to the lack of personal protective equipment, putting Brazil among the countries that most lost health professionals to death.

The Health Financing Commission, an evaluation body of the National Health Council, has been producing weekly information to monitor the execution and expenditure of resources used to combat the pandemic in the country ${ }^{6}$. The data show that, while the cases and deaths caused by the Covid-19 grow exponentially, the Ministry of Health stays weeks in a row without spending most of the budget directed to the pandemic. According to the last Cofin/CNS Bulletin (with data up to June 8), the total amount pledged totaled $\mathrm{R} \$ 26$ billion of the $\mathrm{R} \$ 39$ billion available, that is, $67 \%$ of the available resources $6.76 \%$ of the Ministry of Health's Direct Application 
resources are unused, $60 \%$ are transferred to States, and 66\% are transferred to Municipalities. In comparison to the amounts of the appropriations authorized for each of these applications, the amounts paid represent, respectively, $10 \%, 39 \%$ and $34 \%$ of the total destined 6 .

This situation would be considered a scandal in any civilized country, because, in the midst of a pandemic, with cases and deaths growing exponentially for 16 weeks, the Ministry of Health keeps $67 \%$ of resources unused in the budget, without even being committed to something. It is not just about incompetence, it is a deliberate action not to spend, leaving the SUS and the Brazilian people to their own luck. Contrary to the slowness in the application of the resources so necessary to the SUS at this moment, we can see the speed with which, in the name of the 'war' effort against the pandemic, the government 'protected' the banking system by allowing the purchase of bad bonds from banks, whose losses to public treasure can reach up to several trillion Reais. We should also not forget the government's attempt, promptly aborted by strong criticism from society and the National Congress, to transfer R $\$ 83.9$ million from Bolsa Família to the Secretariat of Communication.

At the same time that the government's disregard and disorientation is astonishingly observed, society sees and is surprised by the daily presence of the public system in the news, in a way never before presented, saving many Brazilians, and suffering the loss of so many of us. It is a feeling of recognition of the SUS and its value as a public good. Interestingly, the private system has left the scene in these pandemic times, although it benefited from the lack of use of routine services by its users cornered by the outbreak, but which keeps their monthly payments up to date. The universal access to the SUS among us contrasts with what we see in the American experience, in which, without a public system, many citizens with symptoms of Covid-19 escape treatment, die at home, in the streets and parks, out of fear of the bill that they could never pay. Here, even with major difficulties, the SUS serves all Brazilians who depend on it, at no cost. It is a right guaranteed to all.

It is too early for predictions and prognoses about the future, but this new status of the importance of the SUS could well represent the strength and political pressure for the consolidation of the system that was created to guarantee the universal right to health and that has hit so many bumps in its way. The biggest one, since it results in solutions to so many proble$\mathrm{ms}$, is to guarantee adequate financing, revoking the spending ceiling and defining a fair and adequate volume of financing for its reinvigoration and consolidation.

This is the time to expand the critical awareness that confers social value to the right to health and the defense of the SUS as a cornerstone of democracy. In this direction, the Brazilian Center for Health Studies (Cebes) has carried out actions along with social movements and with society itself, with emphasis on two recent campaigns that resulted in the mobilization of a diversity of social actors, namely, the \#emdefesadoSUS campaign and the March for the life. We also celebrate and salute young people from the peripheries who lead and mobilize protests against racism and for democracy, in the defense of life.

The Cebes is invested in its responsibility as a political actor in the defense of life and the right to health and in defense of the SUS, and reaffirms its slogan: 'Health is democracy, democracy is health!'.

\section{Collaborators}

Costa AM (0000-0002-1931-3969)*, Rizzotto MLF (0000-0003-3152-1362)* and Lobato LVC (0000-0002-2646-9523)* have equally contributed to the elaboration of the manuscript.
*Orcid (Open Researcher and Contributor ID). 


\section{References}

1. Brasil. Ministério da Saúde. Sistema Nacional de Agravos de Notificação Compulsória. [acesso em 2020 jun 16]. Disponível em: https://portalsinan. saude.gov.br/calendario-epidemiologico-2020.

2. Fundação Oswaldo Cruz. Instituto de Comunicação e Informação Científica e Tecnológica em Saúde. Monitora COVID. [acesso em 2020 jun 17]. Disponível em: https://bigdata-covid19.icict.fiocruz.br/.

3. Fleury S. Golpe na Saúde. [acesso em 2020 jun 16]. Disponível em: https://outraspalavras.net/ crise-brasileira/o-golpe-na-saude/.

4. O Globo. G1. Dados do Datafolha. [acesso em 2020 jun 16]. Disponível em: https://gl.globo.com/ economia/noticia/2020/05/28/auxilio-emergencial-13-de-quem-requisitou-beneficio-nao-recebeu-nenhuma-parcela.ghtml.

5. Abramo HW. Jovens da periferia no centro da cena política. [acesso em 2020 jun 16]. Disponível em: https://teoriaedebate.org.br/2020/06/12/jovens -da-periferia-no-centro-da-cena-politica/.

6. Brasil. Conselho Nacional de Saúde. Boletim COFIN. [acesso em 2020 jun 16]. Disponível em: http://conselho.saude.gov.br/images/comissoes/cofin/boletim/Boletim_2020_0609_T1_2Ae2B_3_4_ate_08_ RB-FF-CO_rev.pdf. 